\section{Fruit Maturity and Timing of Ethylene Treatment Affect Storage Performance of Green Tomatoes at Chilling and Nonchilling Temperatures}

\author{
Sasivimon Chomchalow, ${ }^{1}$ \\ N.M. El Assi, ${ }^{2}$ S.A. Sargent, ${ }^{3}$ \\ and J.K. Brecht ${ }^{4}$
}

\begin{abstract}
Additional INDEX WORDs. Lycopersicon esculentum, ethylene, chilling injury, ripening, marketable life
\end{abstract}

Summary. Green tomato (Lycopersicon esculentum 'Sunny') fruit were stored at $2.5,5,7.5,10$, or $12.5{ }^{\circ} \mathrm{C}(36.5$, $41,45.5,50$, or $54.5{ }^{\circ} \mathrm{F}$ ) for $1,3,5$, or 7 days to determine their sensitivity to chilling injury. In subsequent experiments, fruit were treated with ethylene at $20^{\circ} \mathrm{C}\left(68{ }^{\circ} \mathrm{F}\right)$ until the breaker stage was reached, either before or after storage at $12.5^{\circ} \mathrm{C}$ for $0,1,3,5$, or 7 days, or $2.5^{\circ} \mathrm{C}$ for 3 , 5,7 , or 9 days. Number of days to reach the breaker stage was used as an indicator of initial maturity. The chilling threshold temperature for green 'Sunny' tomatoes was near 7.5 ${ }^{\circ} \mathrm{C}$, with delayed ripening occurring in fruit stored for $\geq \mathbf{5}$ days. Longer exposure times at chilling temperatures resulted in reduced marketable

Horticultural Sciences Department, University of Florida, P. O. Box 110690, Gainesville, FL 32611 0690 .

This research was supported by the Florida Agricultural Experiment Station and approved for publication as journal series R-08221.

${ }^{1}$ Former graduate student. Currently at Department of Botany, Faculty of Science, Chulalongkorn University, Bangkok, 10330, Thailand.

${ }^{2}$ Assistant professor, Department of Horticulture and Plant Protection, College of Agriculture, University of Jordan, P.O. Box 13367, Amman, 11942, Jordan.

${ }^{3}$ Professor.

${ }^{4}$ Professor and corresponding author; e-mail jkb@mail.ifas.ufl.edu. life, dull color, flaccidity, and delayed, uneven (blotchy) and nonuniform ripening. Chemical composition was generally unaffected by chilling, while loss of firmness as a result of chilling exposure time rather than chilling temperatures per se was observed. Increased storage time at either 2.5 or $12.5^{\circ} \mathrm{C}$ accentuated the initial differences in fruit maturity and thus resulted in less uniform ripening, especially for tomatoes stored before ethylene treatment, but the effect was much greater following $2.5{ }^{\circ} \mathrm{C}$ storage. Exposure to $2.5^{\circ} \mathrm{C}$ for as little as 3 days before ethylene treatment caused blotchy ripening and decay, and reduced the marketable life of tomatoes by half compared to storage at nonchilling temperature. Treatment with ethylene before storage prevented chilling injury for up to 5 days at $2.5^{\circ} \mathrm{C}$ and prolonged the marketable life of tomatoes stored at either chilling or nonchilling temperature. Tomatoes became less responsive to poststorage ethylene treatment with increased storage time at either 2.5 or $12.5^{\circ} \mathrm{C}$. More mature tomatoes and those treated with ethylene before $12.5^{\circ} \mathrm{C}$ storage lost less weight. Vitamin $\mathrm{C}$ content was lower in more mature tomatoes, but ethylene treatment resulted in better maintenance of vitamin $\mathbf{C}$ by shortening the time to reach the red stage. No other significant differences in color, firmness or chemical composition at the red stage were found between fruit with different initial maturities or fruit treated with ethylene before or after 2.5 or $\mathbf{1 2 . 5}$ ${ }^{\circ} \mathrm{C}$ storage. Treating green tomatoes with ethylene before storage or transport is preferable to poststorage treatment because of faster and more uniform ripening, and also increased marketable life and reduced risk of injury in the event of exposure to chilling temperatures.

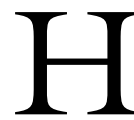
arvesting tomatoes at the mature green stage for fresh market is a practice intended to facilitate postharvest handling while maintaining the quality of fruit that are still firm enough to withstand shipping and handling. Although fruit harvested at later ripeness stages, i.e., turning (Inaba et al., 1980), pink (Kattan, 1957), or red (Kader et al., 1978), possess higher sensory quality at the red stage, these fruit are less tolerant to the current handling and marketing systems. However, tomatoes harvested at the green stage will ripen to a quality level that is acceptable to consumers if they are fully mature at harvest (Kasmire and Kader, 1978).

Commercially, green tomatoes are exposed to ethylene gas, often applied at the packinghouse before shipping, to initiate ripening and shorten the ripening time. Ethylene treatment not only helps maintain fruit quality by hastening the ripening time, but also assures a more homogeneous lot of ripened fruit (Kasmire and Kader, 1978). Since it is difficult to classify tomato maturity at the green stage based on external appearance, a significant amount of tomatoes harvested green may be immature. Immature fruit in a lot ripen more slowly than the rest, resulting in a lack of uniformity in ripening and necessitating resorting and repacking upon arrival at destination markets. This additional handling causes increased mechanical injury, higher labor costs, and higher retail prices. However, some fresh market green tomatoes are shipped without prior exposure to ethylene gas. These fruit are treated with ethylene en route or upon arrival at terminals. This delay in the initiation of ripening raises questions as to possible negative effects on quality of tomatoes in the consumer marketplace (Gull, 1989; Kader et al., 1977, 1978).

Tomatoes in which ripening has not been initiated are more susceptible to chilling injury than riper fruit. Abou Aziz et al. (1974) showed that fruit with more advanced color development developed less chilling injury. After packing, tomatoes may be accidentally exposed to low temperatures in the range of 0 to $12.5^{\circ} \mathrm{C}$ (32 to 54.5 ${ }^{\circ} \mathrm{F}$ ), and as a result, develop chilling injury symptoms such as uneven surface color, excessive softening, pitting, and microbial decay (Dodds and Ludford, 1990; Hall, 1965; Morris, 1954). Postharvest exposure to chilling temperatures usually occurs in transportation vehicles with improper temperature control, during delays in loading and unloading in cold climates, or during holding at improper temperatures in wholesale warehouses and retail stores. Exposing unripe fruit, which are more chilling sensitive, to low temperatures may increase the probability of inducing chilling injury symptoms than exposing ripening initiated fruit.

This study was undertaken to determine the effects of storage period 
and temperature, timing of ethylene treatment, and fruit maturity stage at harvest on uniformity of ripening and fruit quality in tomato. The treatments were designed to simulate commercial postharvest handling conditions that could be encountered in the tomato industry. Fruit quality parameters, i.e., firmness, weight loss, surface color, soluble solids content (SSC), vitamin $\mathrm{C}$ content, $\mathrm{pH}$, and titratable acidity (TA) were evaluated at the red stage. Time to reach the breaker and red stages, and marketable life following the red stage were also determined.

\section{Materials and methods}

'Sunny' tomatoes at the green stage (see below), commercially harvested and packed in 11.34-kg (25-lb) fiberboard cartons, were obtained at different times from five packinghouses in Florida. About 100 packed fruit of three sizes57 to $65 \mathrm{~mm}$ ( $2_{1 / 4}$ to $29 / 16$ inches), 64 to $71 \mathrm{~mm}\left(2_{17 / 32}\right.$ to $25 / 32$ inches), and $>70 \mathrm{~mm}$ (>2 $3 / 4$ inches) diameter (i.e., $6 \times 7,6 \times 6$, and $5 \times 6$ and larger) (Florida Tomato Committee, 1990)were sampled in order to determine the maturity stage (i.e., M1, M2, M3, and M4) based on internal morphology (Kader and Morris, 1976). The size intervals overlap by $1 / 32$ inch to accommodate the mechanical sizing equipment on the packinglines. The fruit were cut transversely and the fruit size class at each sampling time that showed the most uniform distribution of maturity stages was selected for the experiments. Samples of packed fruit were removed from the packing lines and transported by car to Gainesville. After holding overnight at $12.5^{\circ} \mathrm{C}$, the fruit were then sorted for absence of defects or red color and were randomized before assignment to treatments. In total, 75 fruit were used for each treatment.

One experiment was conducted to determine the most appropriate chilling treatment for 'Sunny' tomatoes, and data obtained was used for the storage at chilling temperature experiment. Five temperatures $(2.5,5$, $7.5,10$, and $12.5^{\circ} \mathrm{C}$ ) and four storage periods $(1,3,5$, and $7 \mathrm{~d})$ were assigned by a split plot design. Fruit were ripened at $20^{\circ} \mathrm{C}$ in air upon removal from storage after the assigned treatment period.

Two experiments involving storage at either 2.5 or $12.5^{\circ} \mathrm{C}$ with 10 treatments each were conducted twice using fruit from different harvests. Fruit in the first treatment of each experiment were held continuously at $20^{\circ} \mathrm{C}$ in air as controls. In a second set of four treatments per experiment, the fruit were stored at $2.5^{\circ} \mathrm{C}$ for $3,5,7$, or 9 $\mathrm{d}$ or $12.5^{\circ} \mathrm{C}$ for $1,3,5$, or $7 \mathrm{~d}$, then, upon removal from the storage room on the designated day, treated with ethylene (see below) and held thereafter at $20{ }^{\circ} \mathrm{C}$. In the final set of five treatments per experiment, the fruit were treated with ethylene immediately on the day of harvest. Following the ethylene treatment, fruit from one treatment in each experiment were held at $20^{\circ} \mathrm{C}$ as controls, while fruit in the other four treatments were first stored at $2.5^{\circ} \mathrm{C}$ for $3,5,7$, or $9 \mathrm{~d}$ or $12.5^{\circ} \mathrm{C}$ for $1,3,5$, or $7 \mathrm{~d}$.

Ethylene treatment was carried out using a flow-through system supplying $100 \mu \mathrm{L} \cdot \mathrm{L}^{-1}(\mathrm{ppm})$ ethylene in humidified air [ $(>90 \%$ relative humidity $(\mathrm{RH})]$ at a total flow of $1.34 \mathrm{~L} \cdot \mathrm{min}^{-1}(0.047$ $\mathrm{ft}^{3} / \mathrm{min}$ ). Fruit were placed in $0.75 \times$ $0.45 \times 0.70 \mathrm{~m}(29.5 \times 17.75 \times 27.5$ inch) chambers, left in the dark, and exposed to ethylene at $20{ }^{\circ} \mathrm{C}$. Fruit reaching the breaker stage were marked and counted daily, and left in the chamber. Ethylene treatment was terminated when more than $90 \%$ of the fruit in any treatment reached the breaker stage (i.e., upon appearance of red color). Upon removal from the chambers, three groups (designated as: the least mature; medium mature; and most mature) of 15 color-uniform fruit were selected, based on number of days to reach the breaker stage. Fruit were held at $20{ }^{\circ} \mathrm{C}$ and $70 \%$ to $80 \% \mathrm{RH}$ for completion of ripening following the ethylene treatment or ethylene treatment plus storage at 2.5 or $12.5^{\circ} \mathrm{C}$. Ripening was considered complete at the red stage, which we defined as when the surface color [i.e., the $\mathrm{a}^{*}$ value in the CIE $\mathrm{L}^{*} \mathrm{a}^{*} \mathrm{~b}^{*}$ scale (see below)] measured at the blossom end of a fruit remained constant for two consecutive daily measurements, indicating no further increase in red pigmentation. Uniformity of ripening within a treatment was judged by recording the period of time from harvest until individual fruit reached the red stage. Quality assessments were performed nondestructively on individual red stage fruit; destructive measurements were made at the red stage on three replicates per treatment maturity stage as the 15 fruit in each maturity group were further divided into three subgroups of five uniform fruit. The remaining 30 fruit from each 75-fruit lot were used for determination of the marketable life beyond the red stage (see below).

Nondestructive analyses. Surface color of the fruit at the blossom end was evaluated with a Hunter Lab ColorQUEST Sphere spectrophotometer (Reston, Va.). Light reflectance was measured using Illuminant D65, CIE $\mathrm{L}^{*} \mathrm{a}^{*} \mathrm{~b}$ scale at a $10^{\circ}$ observer angle. Numerical values of $a^{*}$ and $b^{*}$, representing red-green and yellow-blue colors, respectively, were converted into hue angle and chroma values (Francis, 1970). Lower values of hue angle and chroma indicate more red color and lower color purity or intensity, respectively. Weight loss was determined by subtracting the averaged weights of the ripened fruit in each maturity group from their initial averaged weights. Fruit firmness was determined at the red stage by measuring fruit deformation using the IFAS firmness tester developed at the Vegetable Crops Department, University of Florida. A static load of $9.8 \mathrm{~N}(2.2 \mathrm{lb}$ force) was applied to the fruit for $5 \mathrm{~s}$, using a $15.0 \mathrm{~mm}$ diameter convex tip probe. Pressure was applied at two locations over locules on the equator of each fruit. The deformation of each fruit was expressed as a percentage of the fruit diameter (Ahrens and Huber, 1990), with lower values indicating firmer fruit. The deformation values of the five fruit in each maturity subgroup were averaged. Marketable life of the fruit was determined by averaging the number of days beyond the red stage required for most of 30 fruit from each replicate to become unmarketable. Excessive softening, shriveling, and microbial infection determined the termination of marketable life.

Destructive analyses. Soluble solids content of tomato juice was determined using a Abbe refractometer (Bausch and Lomb, Buffalo, N.Y.), reading SSC in ${ }^{\circ} \mathrm{Brix}$ and converting to percent. Titratable acidity of the juice was determined using an automatic titrimeter (Fisher Scientific Co., Pittsburgh, Pa.). The milliequivelent factor for citric acid was used for calculation. The $\mathrm{pH}$ of the juice was determined with a $\mathrm{pH}$ meter (Corning Medical and Scientific Instruments, Medfield, Mass.). Vitamin C content was analyzed using the method of Terada et al. 
(1978). The concentration of ascorbic acid plus dehydroascorbic acid (i.e., vitamin $\mathrm{C}$ ) was calculated as $\mathrm{mg} / \mathrm{l} 00$ $\mathrm{g}$ tissue fresh weight from the absorbance measured at $540 \mathrm{~nm}$ using a standard curve.

Statistical analysis. Five harvests were obtained and three experiments conducted - one harvest to determine the most appropriate chilling treatment and two harvests each for the storage at chilling temperature and storage at nonchilling temperature experiments. Representative results from one harvest for each of the latter two experiments are reported. A split plot design was used for the chilling treatment experiment and a completely randomized design was used in the other two experiments. Analyses of variance (ANOVA) were performed using the Statistical Analysis Systems computer package (SAS Institute, 1986 ) with main effects and interactions evaluated at $P=0.05$. Treatment means were compared by the least significant difference test at $P=0.05$ except for the maturity group means revealing significant differences by ANOVA, which were analyzed separately. Comparison of maturity effects was also by ANOVA at $P=0.05$.

\section{Results}

Chemical composition and maTURITY OF GREEN FRUIT AT HARVEST.

There were no significant differences among maturity stages for SSC of green tomatoes, and only small differences in $\mathrm{pH}, \mathrm{TA}$, and vitamin C content (Table 1). The TA was higher in more mature fruit while $\mathrm{pH}$ and vitamin $\mathrm{C}$ were lower. For the experiments reported here, the maturity distributions were as follows: For fruit in the chilling sensitivity experiment the distribution was $37 \% \mathrm{Ml}, 33 \% \mathrm{M} 2,25 \% \mathrm{M} 3$, and $5 \% \mathrm{M} 4$; for the timing of ethylene treatment experiments, the maturity distribution for the fruit stored at 12.5 ${ }^{\circ} \mathrm{C}$ was $33 \% \mathrm{Ml}, 28 \% \mathrm{M} 2,30 \% \mathrm{M} 3$, and $9 \% \mathrm{M} 4$, and the maturity distribution for the fruit stored at $2.5^{\circ} \mathrm{C}$ was $43 \% \mathrm{Ml}, 30 \% \mathrm{M} 2,20 \% \mathrm{M} 3$, and $5 \%$ M4 (plus 2\% breaker fruit).

Chilling sensitivity of Green 'SUnNy' tomatoes. Increasing the chilling exposure period and decreasing the exposure temperatures delayed time to reach the breaker stage in tomatoes (Fig. 1). Storage for $1 \mathrm{~d}$ at all temperatures resulted in only slight differences in the number of days to the breaker stage. An increase in the number of days to reach the breaker stage occurred with longer storage times and lower temperatures. Fruit stored for $7 \mathrm{~d}$ at $12.5^{\circ} \mathrm{C}$ reached the breaker stage in $11 \mathrm{~d}$, while those stored at $2.5^{\circ} \mathrm{C}$ for the same period of time required $17 \mathrm{~d}$. The temperature of $7.5^{\circ} \mathrm{C}$ appeared to be just below the threshold temperature for chilling injury for these fruit. The days to reach the breaker stage for $2.5,5.0,10.0$, and $12.5{ }^{\circ} \mathrm{C}$ storage increased in a linear fashion as storage time increased (data not shown), while $7.5^{\circ} \mathrm{C}$ storage data appeared to exhibit a curvilinear relationship, i.e., delayed ripening occurred only beyond $3 \mathrm{~d}$ in storage (Fig. 1).

Longer storage periods and lower storage temperatures also increased the number of days to reach the red stage (Fig. 2). Tomatoes held for $1 \mathrm{~d}$ at 12.5 ${ }^{\circ} \mathrm{C}$ reached the red stage in $19 \mathrm{~d}$, whereas, those stored for $7 \mathrm{~d}$ at $\mathbf{1 2 . 5}$ ${ }^{\circ} \mathrm{C}$ required $24 \mathrm{~d}$ to reach the red stage. Clearly, ripening continued at $12.5^{\circ} \mathrm{C}$ at a faster rate than at lower temperatures. Fruit stored for $\mathrm{l} d$ at 5 , 7.5 , or $10^{\circ} \mathrm{C}$ reached the red stage 6 to $8 \mathrm{~d}$ faster than those stored for $7 \mathrm{~d}$ at the same temperatures. A dramatic effect of the lower temperatures occurred in the $2.5^{\circ} \mathrm{C}$ storage treatment: fruit held at $2.5^{\circ} \mathrm{C}$ for $1 \mathrm{~d}$ reached the red stage in $19 \mathrm{~d}$ compared to $31 \mathrm{~d}$ for those fruit first held for $7 \mathrm{~d}$ at the same temperature.

The trend for marketable life of the fruit beyond the red stage was opposite to that above (Fig. 3). Lower storage temperatures and longer storage periods decreased the marketable life of tomatoes. Most of the unmarketable fruit were overripe and very soft. Many of the fruit stored at 2.5 or $5^{\circ} \mathrm{C}$ for 5 or $7 \mathrm{~d}$ before ripening at 20 ${ }^{\circ} \mathrm{C}$ were flaccid, shriveled, and had blotchy surface color. Some of the unmarketable fruit were infected by Alternaria rot (Alternaria alternata), but without a trend showing treatment effect. Storage at $2.5^{\circ} \mathrm{C}$ caused reduction in marketable life for all storage periods; storage at $5{ }^{\circ} \mathrm{C}$ for $\geq 5$ $\mathrm{d}$ reduced marketable life as much as storage at $2.5^{\circ} \mathrm{C}$.

Storage of tomatoes at 2.5 or $5{ }^{\circ} \mathrm{C}$ for 3,5 , or $7 \mathrm{~d}$ resulted in higher chroma and smaller hue angle values than fruit stored for $1 \mathrm{~d}$ at 2.5 or $5{ }^{\circ} \mathrm{C}$ (Table 2). This indicated that fruit stored at chilling temperature for $\geq 3 \mathrm{~d}$

Table 1. Chemical composition of green tomatoes at harvest.

\begin{tabular}{|c|c|c|c|c|c|}
\hline Sample & $\begin{array}{l}\text { Harvest } \\
\text { maturity }\end{array}$ & $\begin{array}{c}\text { Soluble } \\
\text { solids (\%) }\end{array}$ & $\mathbf{p H}$ & $\begin{array}{c}\text { Titratable acidity } \\
\text { (\% citric acid })\end{array}$ & $\begin{array}{c}\text { Vitamin C } \\
\left(\mathrm{mg}^{\prime} 100 \mathrm{~g} \text { fresh } \mathrm{wt}\right)^{\mathrm{z}}\end{array}$ \\
\hline \multirow[t]{3}{*}{ Harvest 1} & $\mathrm{Ml}^{\mathrm{y}}$ & $4.2^{\mathrm{x}}$ & 4.67 & 0.32 & 17.22 \\
\hline & M3 & 4.4 & 4.40 & 0.50 & 15.02 \\
\hline & M4 & 4.3 & 4.30 & 0.53 & 14.91 \\
\hline Significance & & NS & $* * *$ & $* * *$ & * \\
\hline & M2 & 4.3 & 4.40 & 0.55 & 12.55 \\
\hline & M3 & 4.4 & 4.29 & 0.60 & 13.70 \\
\hline & M4 & 4.3 & 4.21 & 0.68 & 12.04 \\
\hline Significance & & NS & $* * *$ & $* * *$ & NS \\
\hline $\operatorname{LSD}_{(0.05)}$ & & & 0.14 & 0.08 & \\
\hline
\end{tabular}

$\mathrm{z} 1.00 \mathrm{mg} / 100 \mathrm{~g}=10 \mathrm{ppm}$

${ }^{\mathrm{y}} \mathrm{Ml}=$ immature-green; $\mathrm{M} 2$ = partially mature-green; $\mathrm{M} 3$ = typically mature-green; M4 = advanced mature-green.

${ }^{\mathrm{x}}$ Means are the average of five fruit.

Ns, $,^{* \star *},{ }^{* \star *}$ Nonsignificant or significant at $P<0.05,0.01$, or 0.001 , respectively. 


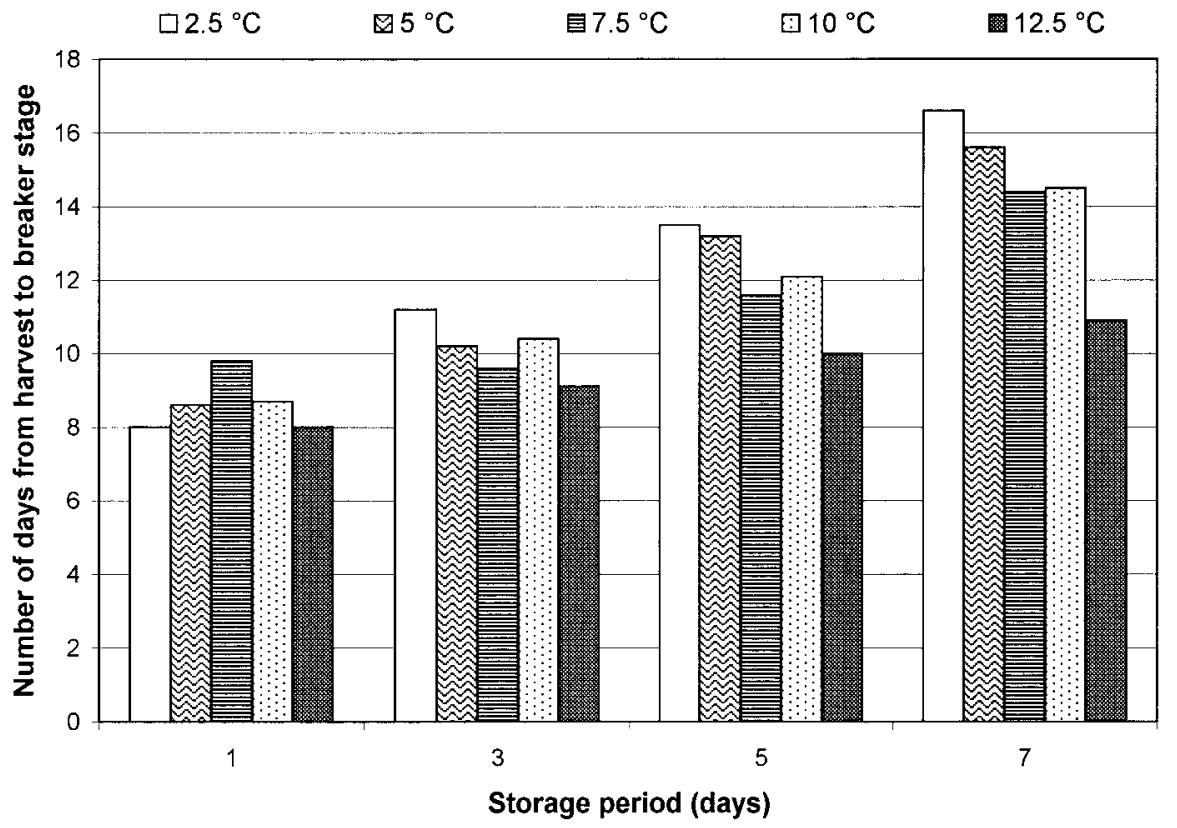

Fig. 1. Number of days to the breaker stage for tomatoes stored at $2.5,5,7.5$, 10 , or $12.5^{\circ} \mathrm{C}\left(36.5,41,45.5,50\right.$, or $\left.54.5^{\circ} \mathrm{F}\right)$ for $1,3,5$, or $7 \mathrm{~d}$, then allowed to ripen in air at $20^{\circ} \mathrm{C}\left(68^{\circ} \mathrm{F}\right)$. Means are the average of 75 fruit. Overall LSD $(P=0.05)=0.2$.

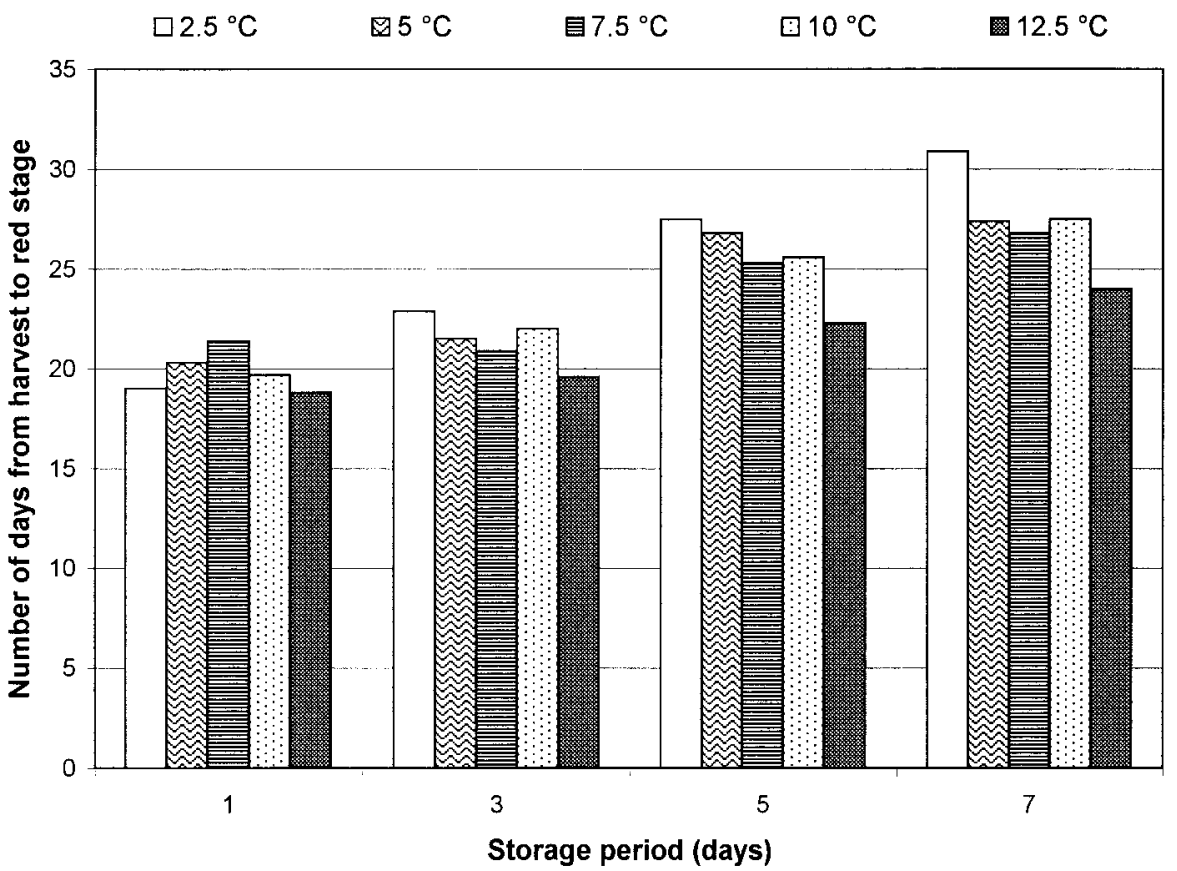

Fig. 2. Number of days to the red stage for tomatoes stored at $2.5,5,7.5,10$, or $12.5{ }^{\circ} \mathrm{C}\left(36.5,41,45.5,50\right.$, or $\left.54.5{ }^{\circ} \mathrm{F}\right)$ for $1,3,5$, or $7 \mathrm{~d}$, then allowed to ripen in air at $20^{\circ} \mathrm{C}\left(68^{\circ} \mathrm{F}\right)$. Means are the average of 75 fruit. Overall LSD $(P=0.05)$ $=0.2$.

were redder, but their color intensity was less than those stored for only $1 \mathrm{~d}$. On the other hand, fruit stored at 2.5, 5 , or $7.5{ }^{\circ} \mathrm{C}$ were less red (i.e., had larger hue angles) than fruit from 10 or $12.5^{\circ} \mathrm{C}$ storage, while the chroma was variable among the storage temperatures. Tomatoes stored for $\geq 5$ d at 2.5 or $5{ }^{\circ} \mathrm{C}$ turned a whitish-green color suggesting loss of chlorophyll and developed a yellow blush on the fruit shoulders during storage; blotchy coloration appeared during ripening at $20{ }^{\circ} \mathrm{C}$.

Storage period affected fruit firmness while storage temperature did not
(Table 2). Holding for 5 or $7 \mathrm{~d}$ resulted in softer fruit compared to holding for 1 or $3 \mathrm{~d}$. At $5^{\circ} \mathrm{C}$, fruit stored for $5 \mathrm{~d}$ were softer than other storage periods, whereas at 7.5 and $10^{\circ} \mathrm{C}$, fruit stored for $7 \mathrm{~d}$ were softer. Storage time at 2.5 or $12.5^{\circ} \mathrm{C}$ did not affect firmness.

Chemical composition, i.e., SSC, vitamin $\mathrm{C}$ content, $\mathrm{pH}$, and $\mathrm{TA}$, was generally unaffected by storage period or temperature (data not shown). However, vitamin $\mathrm{C}$ content tended to increase with longer storage periods at 10 or $12.5^{\circ} \mathrm{C}$ (data not shown).

TIMING OF ETHYLENE TREATMENT: Storage AT NONCHILling temperaTURE. In general, tomatoes that were subject to poststorage ethylene treatment required more time to reach the breaker stage than those treated with ethylene immediately on the day of harvest and then held for different durations of time at $12.5{ }^{\circ} \mathrm{C}$ (Fig. 4). While about a 4-d ethylene exposure was required for these tomatoes to reach the breaker stage when they were treated before storage, the ethylene treatment time necessary for the breaker stage to be reached increased to as much as $9 \mathrm{~d}$ for fruit first stored for $7 \mathrm{~d}$ at $12.5{ }^{\circ} \mathrm{C}$. In addition, the longer the storage period either before or after ethylene treatment, the longer was the delay in reaching the red stage, with fruit treated with ethylene after storage requiring more time than those treated before storage (Fig. 4). The latter effect was because the fruit in the prestorage ethylene treatments continued to ripen slowly in storage at $12.5{ }^{\circ} \mathrm{C}$ while the fruit in the poststorage ethylene treatments remained green. Thus, tomatoes stored at $12.5{ }^{\circ} \mathrm{C}$ for $7 \mathrm{~d}$ before ethylene treatment ripened the slowest: $19 \mathrm{~d}$ compared to $16 \mathrm{~d}$ for fruit treated with ethylene before storage for $7 \mathrm{~d}$. Fruit held continuously in air at $20^{\circ} \mathrm{C}$ without ethylene treatment also required $16 \mathrm{~d}$ to reach the red stage, whereas, those that were treated with ethylene before holding in air at $20^{\circ} \mathrm{C}$ required $14 \mathrm{~d}$ to ripen. The marketable life of tomatoes beyond the red stage in air at $20^{\circ} \mathrm{C}$ was not significantly affected by timing of ethylene treatment or by storage time at $12.5^{\circ} \mathrm{C}$ (Fig. 4). Most unmarketable fruit were very soft; some were shriveled or infected at mechanical wound sites.

Tomatoes stored at $12.5^{\circ} \mathrm{C}$ before ethylene treatment were redder 


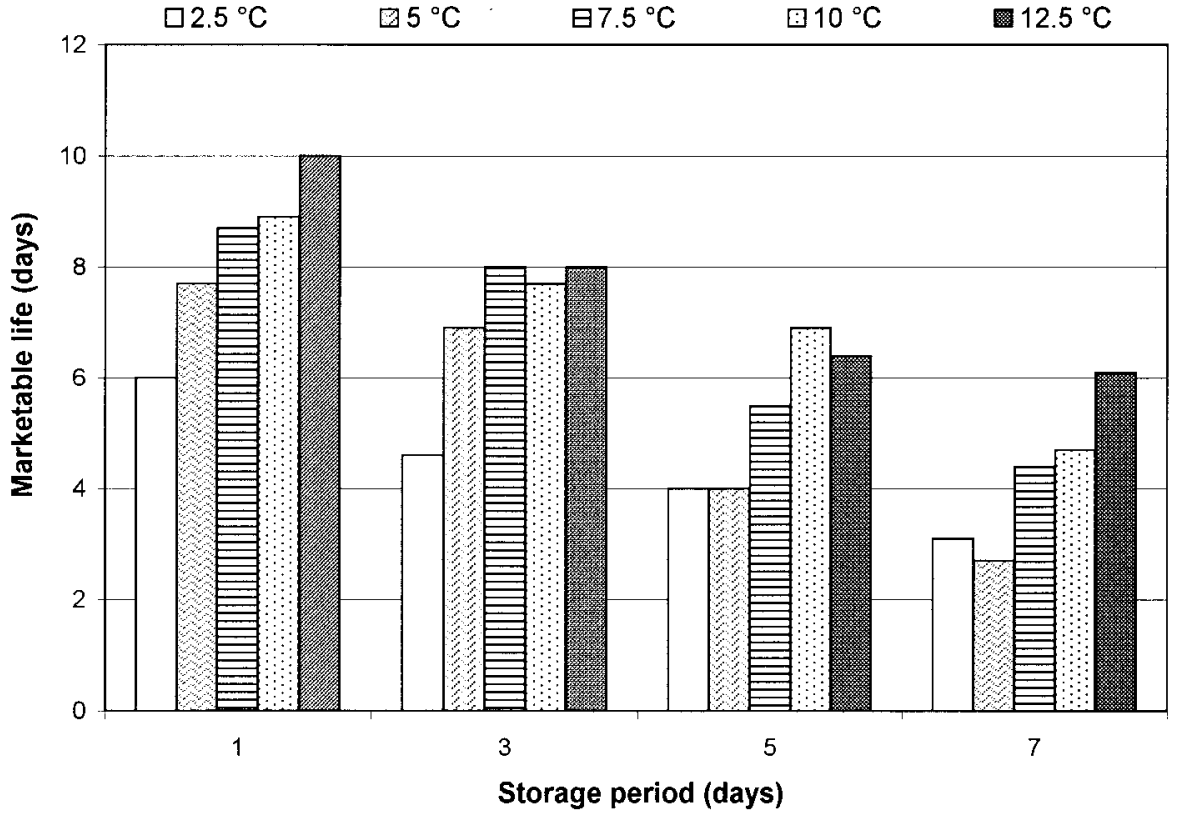

Fig. 3. Marketable life beyond the red stage of tomatoes stored at 2.5, 5, 7.5, 10 , or $12.5^{\circ} \mathrm{C}\left(36.5,41,45.5,50\right.$, or $\left.54.5^{\circ} \mathrm{F}\right)$ for $1,3,5$, or $7 \mathrm{~d}$, then allowed to ripen in air at $20^{\circ} \mathrm{C}\left(68^{\circ} \mathrm{F}\right)$. Means are the average of 30 fruit. Overall LSD $(P=0.05)=0.5$.

with more intense color (i.e., had lower hue angle and higher chroma values) at the red stage than those treated with ethylene immediately on the day of harvest and then stored (Table 3 ). With prestorage ethylene treatment, the storage period in air at $12.5^{\circ} \mathrm{C}$ slightly affected fruit surface color, i.e., fruit stored longer were redder than fruit stored for shorter periods. Uneven coloration developed in fruit stored for 5 or $7 \mathrm{~d}$ at $12.5^{\circ} \mathrm{C}$ before ethylene treatment, however, the ultimate surface color appeared to be normal.

The faster ripening tomatoes, i.e., those treated with ethylene immediately on the day of harvest before storage at $12.5^{\circ} \mathrm{C}$, lost the least weight, while the nonstored fruit without ethylene treatment had significantly greater weight loss despite being held an average of only $\mathrm{l} \mathrm{d}$ longer at $20^{\circ} \mathrm{C}$ (Table 3). The most mature fruit lost less weight than the medium and least mature fruit. Storage time at $12.5^{\circ} \mathrm{C}$ adversely affected weight loss, as higher weight loss was generally observed for fruit stored longer. With prestorage ethylene treatment, less mature fruit were softer than more mature fruit, but with poststorage ethylene treatment, firmness was more variable and the least mature fruit were firmer than the more mature fruit (Table 3 ).

The SSC at the red stage was only slightly affected by the initial fruit maturity or by the storage and ethylene treatments with no clear trend (Table 4). The $\mathrm{pH}$ and TA of the tomatoes were also slightly affected by maturity, with higher $\mathrm{pH}$ and lower TA in the most mature fruit; treatment differences were quite small (Table 4).

Table 2. Color and firmness of red stage tomatoes stored in air at $2.5,5,7.5,10$, or $12.5{ }^{\circ} \mathrm{C}(36.5,41,45.5,50$, or 54.5 ${ }^{\circ} \mathrm{F}$ ) for $1,3,5$, or $7 \mathrm{~d}$ then allowed to ripen in air at $20^{\circ} \mathrm{C}\left(68^{\circ} \mathrm{F}\right)$.

\begin{tabular}{|c|c|c|c|c|c|c|c|c|c|}
\hline \multirow{2}{*}{$\begin{array}{l}\text { Storage } \\
\text { period } \\
\text { (d) } \\
\end{array}$} & \multirow[b]{2}{*}{ Parameter $^{\mathrm{z}}$} & \multicolumn{5}{|c|}{ Storage temp $\left[{ }^{\circ} \mathbf{C}\left({ }^{\circ} \mathbf{F}\right)\right]$} & \multirow[b]{2}{*}{ Means } & \multirow[b]{2}{*}{ Significance } & \multirow{2}{*}{$\begin{array}{c}\text { LSD } \\
(P=\mathbf{0 . 0 5})\end{array}$} \\
\hline & & $2.5(36.5)$ & $5(41)$ & $7.5(45.5)$ & $10(50)$ & $12.5(54.5)$ & & & \\
\hline & Hue angle & 40.14 & 40.31 & 39.42 & 40.05 & 39.05 & 39.68 & & \\
\hline & Deformation (\%) & 5.23 & 4.61 & 4.94 & 4.87 & 5.25 & 4.98 & & \\
\hline 3 & Chroma & 45.23 & 45.55 & 46.25 & 45.78 & 46.32 & 45.82 & & \\
\hline \multirow[t]{3}{*}{5} & Chroma & 44.98 & 44.99 & 45.97 & 46.68 & 46.68 & 45.73 & & \\
\hline & Hue angle & 38.71 & 39.13 & 38.46 & 39.81 & 39.89 & 39.20 & & \\
\hline & Deformation (\%) & 5.42 & 6.60 & 5.46 & 5.10 & 5.55 & 5.63 & & \\
\hline \multirow[t]{2}{*}{7} & Chroma & 45.56 & 44.63 & 46.11 & 45.65 & 45.48 & 45.49 & & \\
\hline & Hue angle & 39.20 & 37.70 & 39.66 & 39.77 & 40.14 & 39.30 & & \\
\hline \multirow[t]{3}{*}{ Significance } & Chroma & ** & * & NS & NS & NS & * & $*$ & \\
\hline & Hue angle & ** & $* * *$ & NS & NS & NS & $* * *$ & ** & \\
\hline & Deformation & NS & $* * *$ & ** & ** & NS & $\star *$ & ** & \\
\hline \multirow{3}{*}{$\operatorname{LSD}_{(0.05)}$} & Chroma & 1.26 & 1.15 & & & & 0.60 & & \\
\hline & Hue angle & 0.95 & 0.84 & & & & 0.49 & & \\
\hline & Deformation & & 0.81 & 0.74 & 0.68 & & 0.31 & & \\
\hline
\end{tabular}

${ }^{\mathrm{z}}$ Chroma $=\left(\mathrm{a}^{\star 2}+\mathrm{b}^{\star 2}\right)^{1 / 2}$; hue angle $=\tan ^{-1} \mathrm{~b}^{*} / \mathrm{a}^{*} ;$ deformation $=\%$ of fruit diameter after $5 \mathrm{~s}$ under a $9.8 \mathrm{~N}(2.2 \mathrm{lb}$ force $)$ static load

y Means are the average of 45 fruit.

Ns, $,{ }^{\star \star \star},{ }^{* \star *}$ Nonsignificant or significant at $P<0.05,0.01$, or 0.001 , respectively. 


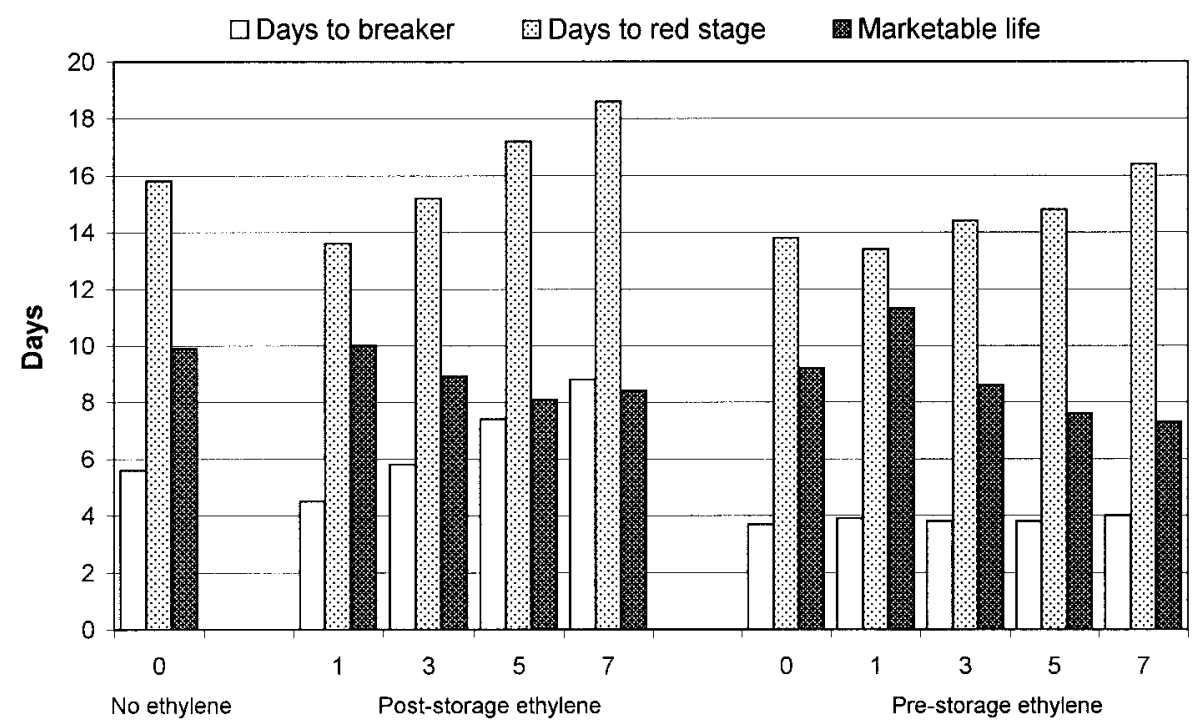

Storage period (days at $12.5^{\circ} \mathrm{C}$ )

Fig. 4. Number of days to breaker and red stages, and marketable life beyond the red stage of tomatoes treated with ethylene at $20^{\circ} \mathrm{C}\left(68^{\circ} \mathrm{F}\right)$ before or after storage in air at $12.5^{\circ} \mathrm{C}\left(54.5{ }^{\circ} \mathrm{F}\right)$, then held in air at $20^{\circ} \mathrm{C}\left(68^{\circ} \mathrm{F}\right)$. Means for the number of days to breaker and red stages are the average of 75 fruit, while those for the marketable life are the average of 30 fruit. Overall LSD $(P=0.05)$ for days to breaker, days to red stage, and marketable life $=0.5,0.6$, and ns, respectively.

Treatment effects on vitamin C content were apparent only on the most mature fruit (Table 4). Vitamin C content was generally higher in the nonstored fruit, especially those treated with ethylene.

Timing OF ETHYLENE TREATMENT: Storage At ChILling temperature.
The time at $20^{\circ} \mathrm{C}$ required for tomatoes to reach the breaker or red stage was a function of the timing of ethylene application. Without ethylene treatment, these tomatoes reached the breaker stage in $6 \mathrm{~d}$ (Fig. 5). The breaker stage was reached in $3 \mathrm{~d}$ when the fruit were treated with ethylene before storage, however, the ethylene treatment time necessary for the breaker stage to be reached increased to $11 \mathrm{~d}$ for fruit first stored for $9 \mathrm{~d}$ at $2.5^{\circ} \mathrm{C}$ before ethylene treatment. The ripening time increased as the length of storage, either before or after ethylene treatment, increased. Tomatoes treated with ethylene on the day of harvest and held in air at $20^{\circ} \mathrm{C}$ reached the red stage in $8 \mathrm{~d}$, while the fruit not exposed to ethylene required $11 \mathrm{~d}$ (Fig. 5). Fruit stored at $2.5^{\circ} \mathrm{C}$ before ethylene treatment required 14 to $19 \mathrm{~d}$ to reach the red stage. The same trend of increased ripening time with longer storage was observed in the prestorage ethylene-treated fruit, but with 2 - or $3-d$ shorter durations than the poststorage ethylene-treated fruit. The shortest time required for the fruit to reach the red stage $(8 \mathrm{~d})$ was observed in the fruit treated with ethylene immediately on the day of harvest and held continuously afterwards in air at $20^{\circ} \mathrm{C}$ without storage at $2.5^{\circ} \mathrm{C}$.

An opposite trend was observed for the marketable life of the tomatoes at $20^{\circ} \mathrm{C}$ following the red stage. In general, poststorage ethylene-treated fruit had less marketable life compared to prestorage ethylene-treated fruit (Fig. 5). Additionally, the longer the duration of the storage period at 2.5 ${ }^{\circ} \mathrm{C}$, either before or after ethylene application, the shorter the marketable life became. Exposure to $2.5^{\circ} \mathrm{C}$ for as

Table 3. Color, weight loss, and firmness of red stage tomatoes treated with ethylene at $20^{\circ} \mathrm{C}\left(68{ }^{\circ} \mathrm{F}\right)$ before or after storage in air at $12.5{ }^{\circ} \mathrm{C}\left(54.5^{\circ} \mathrm{F}\right)$ for $1,3,5$, or $7 \mathrm{~d}$ then allowed to ripen in air at $20^{\circ} \mathrm{C}$.

\begin{tabular}{|c|c|c|c|c|c|c|c|c|c|c|c|c|c|}
\hline \multicolumn{2}{|c|}{$\begin{array}{l}\text { Postharvest } \\
\text { treatment before } \\
\text { ripening at } 20^{\circ} \mathrm{C} \\
\end{array}$} & \multicolumn{3}{|c|}{ Hue angle $^{\mathrm{z}}$} & \multicolumn{3}{|c|}{ Chroma $^{\mathrm{z}}$} & \multicolumn{3}{|c|}{ Wt loss (\%) } & \multicolumn{3}{|c|}{ Deformation $(\%)^{\mathrm{z}}$} \\
\hline $\begin{array}{l}\text { Storage } \\
\text { period at }\end{array}$ & $\begin{array}{c}\text { Ethylene } \\
\text { treatment }\end{array}$ & & & & & & $\begin{array}{l}\text { Maturit } \\
\text { Ibgrou }\end{array}$ & & & & & & \\
\hline $12.5^{\circ} \mathrm{C}(\mathrm{d})$ & at $20^{\circ} \mathrm{C}$ & Least & Med & Most & Least & Med & Most & Least & Med & Most & Least & Med & Most \\
\hline 0 (Control) & None & $39.16^{x}$ & 39.04 & 40.28 & 48.26 & 47.24 & 47.02 & 6.64 & 6.06 & 5.44 & 5.31 & 5.68 & 5.58 \\
\hline 1 & Poststorage & 40.45 & 40.69 & 40.88 & 48.41 & 47.31 & 46.76 & 4.76 & 4.46 & 4.43 & 6.09 & 6.03 & 6.78 \\
\hline 3 & Poststorage & 40.36 & 40.01 & 41.30 & 48.24 & 46.93 & 47.02 & 5.52 & 3.57 & 3.86 & 5.48 & 5.10 & 6.14 \\
\hline 5 & Poststorage & 37.37 & 39.09 & 41.10 & 46.30 & 47.23 & 45.34 & 4.51 & 4.44 & 4.35 & 5.45 & 5.17 & 6.13 \\
\hline 7 & Poststorage & 40.46 & 38.23 & 39.48 & 47.83 & 46.26 & 45.81 & 4.79 & 3.72 & 4.26 & 5.26 & 4.94 & 6.40 \\
\hline 0 (Control) & Prestorage & 41.59 & 40.17 & 39.68 & 47.84 & 46.96 & 46.97 & 4.78 & 5.23 & 4.02 & 6.72 & 6.50 & 5.96 \\
\hline 1 & Prestorage & 40.54 & 40.55 & 40.76 & 48.84 & 46.87 & 47.28 & 4.51 & 4.36 & 4.44 & 6.12 & 5.94 & 5.40 \\
\hline 3 & Prestorage & 40.14 & 39.40 & 40.70 & 47.46 & 46.85 & 47.17 & 3.71 & 3.66 & 3.29 & 6.33 & 6.50 & 6.67 \\
\hline 5 & Prestorage & 40.34 & 40.63 & 41.11 & 47.34 & 47.42 & 46.18 & 4.20 & 3.55 & 3.68 & 5.57 & 5.32 & 6.40 \\
\hline 7 & Prestorage & 40.10 & 40.26 & 40.74 & 47.27 & 46.44 & 46.66 & 4.00 & 3.87 & 3.92 & 4.97 & 6.52 & 6.10 \\
\hline Significance & & $* * *$ & $* * *$ & * & $* *$ & NS & $\star * *$ & $* * *$ & $* * *$ & $* * *$ & $\star * *$ & $* * *$ & * \\
\hline $\operatorname{LSD}_{(0.05)}$ & & 1.00 & 1.08 & 1.19 & 0.80 & & 0.97 & 0.60 & 0.47 & 0.50 & 0.75 & 0.78 & 0.84 \\
\hline
\end{tabular}

${ }^{\mathrm{z}}$ Chroma $=\left(\mathrm{a}^{\star 2}+\mathrm{b}^{\star 2}\right)^{1 / 2}$; hue angle $=\tan ^{-1} \mathrm{~b}^{*} / \mathrm{a}^{\star}$; deformation $=\%$ of fruit diameter after $5 \mathrm{~s}$ under a $9.8 \mathrm{~N}(2.2 \mathrm{lb}$ force $)$ static load

${ }^{\prime}$ Least $=$ least mature fruit; med $=$ medium mature fruit; most $=$ most mature fruit.

${ }^{\mathrm{x}}$ Means are the average of 15 fruit.

Ns, $,{ }^{\star \star *},{ }^{\star \star *}$ Nonsignificant or significant at $P<0.05,0.01$, or 0.001 , respectively. 
Table 4. Composition of red stage tomatoes treated with ethylene at $20^{\circ} \mathrm{C}\left(68{ }^{\circ} \mathrm{F}\right)$ before or after storage in air at $12.5{ }^{\circ} \mathrm{C}$ $\left(54.5{ }^{\circ} \mathrm{F}\right)$ for $1,3,5$, or $7 \mathrm{~d}$ then allowed to ripen in air at $20^{\circ} \mathrm{C}$.

\begin{tabular}{|c|c|c|c|c|c|c|c|c|c|c|c|c|c|}
\hline \multicolumn{2}{|c|}{$\begin{array}{c}\text { Postharvest } \\
\text { treatment before } \\
\text { ripening at } 20^{\circ} \mathrm{C} \\
\end{array}$} & \multicolumn{3}{|c|}{$\begin{array}{c}\text { Soluble } \\
\text { solids } \\
\text { content }(\%) \\
\end{array}$} & \multicolumn{3}{|c|}{ pH } & \multicolumn{3}{|c|}{$\begin{array}{c}\text { Titratable } \\
\text { acidity } \\
\text { (\% citric acid) }\end{array}$} & \multicolumn{3}{|c|}{$\begin{array}{c}\text { Vitamin C } \\
(\mathrm{mg} / \mathbf{1 0 0} \mathrm{g} \text { fresh } \mathrm{wt})^{\mathrm{z}}\end{array}$} \\
\hline $\begin{array}{l}\text { Storage } \\
\text { period at }\end{array}$ & $\begin{array}{c}\text { Ethylene } \\
\text { treatment }\end{array}$ & \multicolumn{9}{|c|}{$\begin{array}{c}\text { Maturity } \\
\text { subgroup }^{\mathrm{y}}\end{array}$} & & & \\
\hline $12.5^{\circ} \mathrm{C}(\mathrm{d})$ & at $20^{\circ} \mathrm{C}$ & Least & Med & Most & Least & Med & Most & Least & Med & Most & Least & Med & Most \\
\hline 0 (Control) & None & $3.7^{\mathrm{x}}$ & 3.8 & 3.2 & 4.23 & 4.22 & 4.29 & 0.46 & 0.40 & 0.36 & 15.86 & 17.86 & 17.60 \\
\hline 5 & Poststorage & 3.7 & 4.1 & 2.7 & 4.22 & 4.23 & 4.26 & 0.41 & 0.47 & 0.35 & 17.69 & 19.48 & 12.88 \\
\hline 7 & Poststorage & 3.7 & 3.6 & 3.4 & 4.22 & 4.22 & 4.25 & 0.41 & 0.37 & 0.36 & 16.15 & 19.73 & 13.09 \\
\hline 0 (Control) & Prestorage & 3.1 & 3.6 & 3.2 & 4.19 & 4.36 & 4.29 & 0.37 & 0.44 & 0.35 & 18.90 & 23.48 & 16.90 \\
\hline 1 & Prestorage & 3.4 & 3.1 & 3.4 & 4.18 & 4.24 & 4.26 & 0.39 & 0.31 & 0.39 & 17.71 & 16.99 & 14.00 \\
\hline 3 & Prestorage & 3.1 & 3.4 & 3.0 & 4.21 & 4.26 & 4.31 & 0.36 & 0.34 & 0.32 & 17.82 & 21.73 & 13.72 \\
\hline
\end{tabular}

${ }^{\mathrm{z}} 1.00 \mathrm{mg} / 100 \mathrm{~g}=10 \mathrm{ppm}$.

yLeast $=$ least mature fruit; Med $=$ medium mature fruit; Most $=$ most mature fruit.

${ }^{\mathrm{x}}$ Means are the average of three 5 -fruit replications.

Ns, $,{ }^{\star \star * *},{ }^{\star * *}$ Nonsignificant or significant at $P<0.05,0.01$, or 0.001 , respectively.

little as $3 \mathrm{~d}$ before ethylene treatment reduced the marketable life of tomatoes by half compared to storage at nonchilling temperature. Fruit stored in air at $2.5^{\circ} \mathrm{C}$ for 3,5 , or $7 \mathrm{~d}$ after ethylene treatment kept for about $7 \mathrm{~d}$ after they ripened, while those stored for $9 \mathrm{~d}$ at $2.5^{\circ} \mathrm{C}$ lasted for only $5 \mathrm{~d}$. Most of the fruit that were unmarketable after prestorage ethylene treatment and ripening in air at $20^{\circ} \mathrm{C}$ were soft without any abnormal characteristics, in contrast to the tomatoes first stored at $2.5^{\circ} \mathrm{C}$ then exposed to ethylene, which developed chilling injury.

Although the tomatoes chilled before ethylene treatment were eventually judged ripe when most of the surface area was red, the surface color development was not uniform, resulting in blotchy appearance. Additionally, their surface texture was coarse and the color dull. In contrast, the fruit stored at $2.5{ }^{\circ} \mathrm{C}$ after ethylene treatment developed uniform, although orange-red, surface color. Hue angle was not affected by maturity but was affected by treatment (Table 5). Ethylene treatment before chilling exposure resulted in larger hue angle values, compared to the poststorage ethylene-treated fruit. Fruit stored longer at $2.5^{\circ} \mathrm{C}$, whether treated with ethylene before or after storage, were not as red as those stored for shorter periods, as indicated by the larger hue angle values. The chroma values were lower in more mature fruit from the poststorage ethylene treatments, but were not consistently affected by storage time for either prestorage or poststorage ethylene (Table 5 ).

Treatment with ethylene before or after storage at $2.5^{\circ} \mathrm{C}$ had opposite effects on the firmness of the least mature and most mature tomatoes
(Table 5). The least mature fruit were softer at the red stage when treated with ethylene before $2.5^{\circ} \mathrm{C}$ storage, while the most mature fruit were softer when treated with ethylene after 2.5 ${ }^{\circ} \mathrm{C}$ storage. The firmness of the medium maturity fruit at the red stage was not affected by the timing of the ethylene treatment.

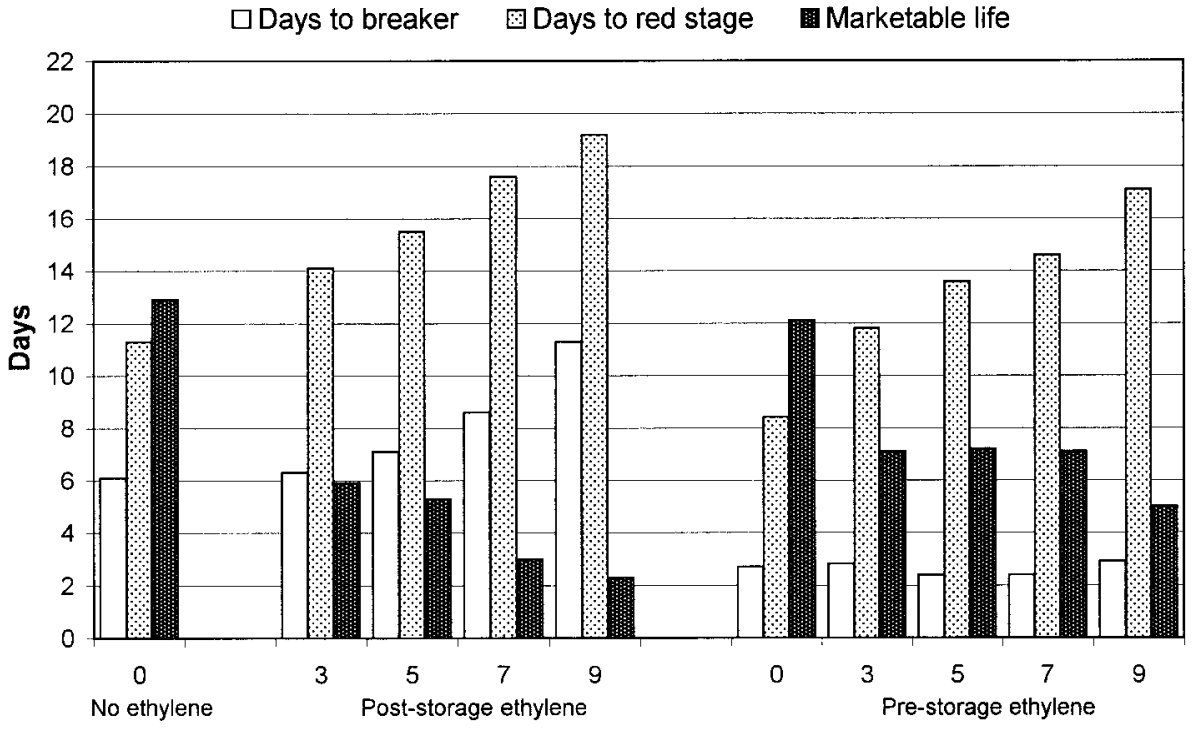

Storage period (days at $2.5^{\circ} \mathrm{C}$ )

Fig. 5. Number of days to breaker and red stages, and marketable life beyond the red stage of tomatoes treated with ethylene at $20^{\circ} \mathrm{C}\left(68^{\circ} \mathrm{F}\right)$ before or after storage in air at $2.5^{\circ} \mathrm{C}\left(36.5^{\circ} \mathrm{F}\right)$, then held in air at $20^{\circ} \mathrm{C}\left(68^{\circ} \mathrm{F}\right)$. Means for the number of days to breaker and red stages are the average of 75 fruit, while those for the marketable life are the average of 30 fruit. Overall LSD $(P=0.05)$ for days to breaker, days to red stage, and marketable life $=1.4,0.8$, and 1.8 , respectively. 
Timing of ethylene treatment and storage at $2.5^{\circ} \mathrm{C}$ had little or no effect on SSC, pH, or TA levels measured at the red stage (Table 6). Maturity differences were also very small, with decreases in SSC and TA of only $0.36 \%$ and $0.05 \%$, respectively, and an increase in $\mathrm{pH}$ of only 0.04 units from the least to the most mature fruit. Vitamin C content of red stage tomatoes was not affected by initial fruit maturity, but was lowest in the nonethylene-treated control, and tended to increase with longer storage time at $2.5^{\circ} \mathrm{C}$ (Table 6).

\section{Discussion}

It has been established that delayed, partial, or uneven ripening are chilling injury symptoms (McColloch and Worthington, 1952), and that the occurrence of chilling injury requires interaction between storage temperature and time (Wang, 1982). Hobson (1987), Autio and Bramlage (1986), and Whitaker (1991) have previously observed that tomatoes stored at 15 ${ }^{\circ} \mathrm{C}\left(59^{\circ} \mathrm{F}\right)$ progressed normally to the pink stage, while fruit stored at $2{ }^{\circ} \mathrm{C}$ $\left(35.6^{\circ} \mathrm{F}\right)$ did not ripen. In our experiment, ripening of tomatoes upon transfer from chilling to nonchilling temperatures was delayed by increased storage periods and lower storage temperature. The marketable life of the tomatoes stored at chilling temperature was reduced significantly, which is in agreement with Jackman et al. (1989). The uneven coloration, which is frequently observed in chilled tomatoes (Hardenburg et al., 1986), was the major cause of marketable life termination of chilled fruit in our experiment.

Pale-green and yellow-blush coloration evident on the fruit exposed to chilling temperatures was probably the result of damaged chloroplasts (Marangoni et al., 1989; Moline, 1976). Dodds et al. (1991) suggested that decreased levels of chlorophyll in chilled tomatoes likely unveils $\beta$-carotene, causing the appearance of yellow blush color. Chilling may also have caused accumulation of chalconaringenin, a yellow compound found in tomato pericarp (Baker et al., 1982). While storage at $2^{\circ} \mathrm{C}$ for $14 \mathrm{~d}$ resulted in the inhibition of red color development (McDonald et al., 1999), thus the appearance of blotchy fruit (Hobson, 1987), in our experiment only slight differences in the final surface color of the fruit among treatments were detected due to the shorter storage period $(7 \mathrm{~d})$ at chilling temperature $\left(2.5\right.$ and $\left.5{ }^{\circ} \mathrm{C}\right)$.

Tomatoes stored at $5{ }^{\circ} \mathrm{C}$ for $15 \mathrm{~d}$ have been reported to exhibit enhanced softening during subsequent ripening at $22^{\circ} \mathrm{C}\left(71.6^{\circ} \mathrm{F}\right)$ (Marangoni et al., 1995). Softening might have been enhanced by elevated ethylene levels produced in response to chilling stress.
Nevertheless, Marangoni et al. (1995) reported that tomatoes held at $2{ }^{\circ} \mathrm{C}$ for $14 \mathrm{~d}$ and then ripened were firmer than nonchilled fruit at the red stage. Chemical composition could not be used as an accurate reflection of chilling injury symptoms, since little or no significant differences were found due to storage temperatures or storage time. It should be noted here that Marangoni et al. (1995) used only medium mature fruit for their chemical analyses.

Morris (1954) reported that chilling injury in tomatoes occurred following $10 \mathrm{~d}$ at $10^{\circ} \mathrm{C}$, however, in this experiment, there was no chilling injury following $7 \mathrm{~d}$ at $10^{\circ} \mathrm{C}$. Noticeably, there was an apparent shift from no chilling injury after 1 or $3 \mathrm{~d}$ to injury after 5 or $7 \mathrm{~d}$ at $7.5^{\circ} \mathrm{C}$. Therefore, the threshold for chilling in green 'Sunny' tomatoes appears to be between 7.5 and $10^{\circ} \mathrm{C}$ for a 5 -d storage.

Results obtained on the number of days required for tomatoes treated with ethylene to reach the red stage compared to untreated fruit confirm previous reports by Rosa (1926) and Pratt and Workman (1962) demonstrating that ethylene application hastens fruit ripening and promotes uniformity of ripeness in treated tomatoes. However, rather than an acceleration of an already initiated ripening process, faster ripening actually resulted from earlier ripening initiation (Pratt and Workman, 1962). It appeared that

Table 5. Color, weight loss, and firmness of red stage tomatoes treated with ethylene at $20{ }^{\circ} \mathrm{C}\left(68{ }^{\circ} \mathrm{F}\right)$ before or after storage in air at $2.5^{\circ} \mathrm{C}\left(36.5{ }^{\circ} \mathrm{F}\right)$ for $3,5,7$, or $9 \mathrm{~d}$ then allowed to ripen in air at $20^{\circ} \mathrm{C}$.

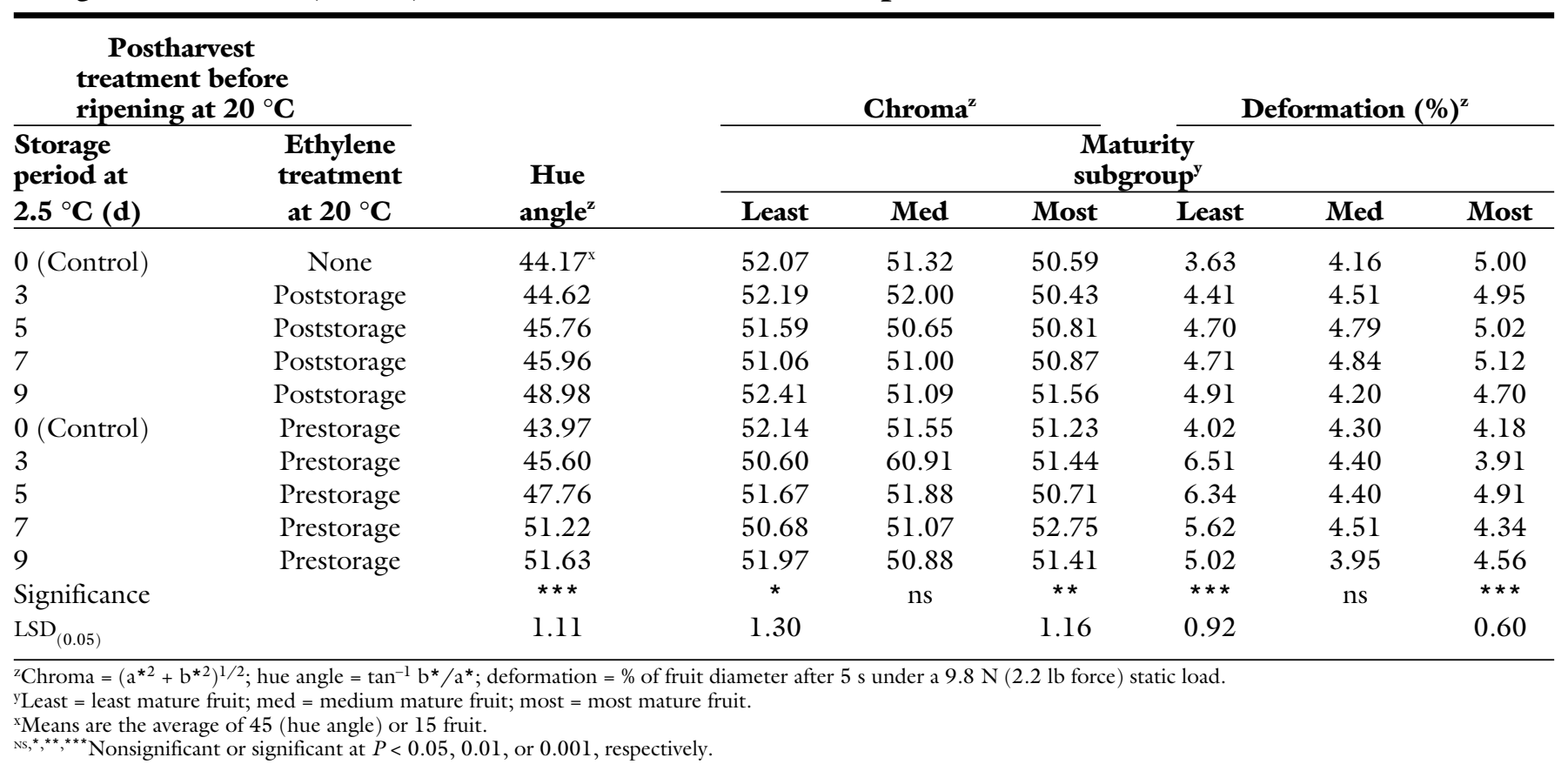


ripening that was already initiated by ethylene exposure before storage continued during storage at $12.5^{\circ} \mathrm{C}$. This advancement in ripeness in prestorage ethylene treatments appeared to hasten subsequent ripening at $20^{\circ} \mathrm{C}$ after removal from storage. On the other hand, our results showed that the ripening time of tomatoes was extended when storage at $12.5^{\circ} \mathrm{C}$ occurred before ethylene treatment but not after ethylene exposure. The delay in ripening following storage at $12.5^{\circ} \mathrm{C}$ is in agreement with similar findings of Kader et al. (1978). Delay in ripening initiation in storage at $12.5^{\circ} \mathrm{C}$ may be due to a general suppression of biochemical processes including development of pigments, synthesis of polygalacturonase, and ethylene production, similar to those observed in modified atmosphere storage (Brown et al., 1989; Burg and Burg, 1967; Goodenough et al., 1982; Jeffery et al., 1984). Additionally, nonuniform ripening was apparent at an early phase of the red stage as a consequence of lack of ripeness uniformity even before reaching the breaker stage.

Storage at $12.5^{\circ} \mathrm{C}$ for 5 or $7 \mathrm{~d}$ before ethylene treatment at $20{ }^{\circ} \mathrm{C}$ resulted in uneven coloration as previously reported for tomatoes stored for $11 \mathrm{~d}$ at $12.5^{\circ} \mathrm{C}$ in air (Brown et al., 1989). However, in our experiment, when the tomatoes were removed from storage, treated with ethylene, and ripened in air at $20^{\circ} \mathrm{C}$, surface color developed rapidly and appeared normal at the red stage. It seemed that storage at $12.5^{\circ} \mathrm{C}$ had a dual effect and its role was dictated by the timing of ethylene application. Storage at 12.5 ${ }^{\circ} \mathrm{C}$ for $\leq 7 \mathrm{~d}$ retarded, but did not completely inhibit, the development of red color. Fruit treated with ethylene before storage showed incipient red surface color before storage, and color development continued during storage. Although tomatoes treated with ethylene before storage exhibited less red color at the red stage than tomatoes treated with ethylene after storage, the differences were hardly visually perceptible.

The fastest to ripen tomatoes (i.e., those in storage for shorter periods) and the most mature fruit lost the least weight. Weight loss was more evident the longer fruit had to be held at $20^{\circ} \mathrm{C}$ to complete ripening. Initial softening of tomatoes treated with ethylene before storage, especially the more mature fruit, was likely partly a result of earlier liquefaction of the locule gel (Ahrens and Huber, 1990; Brecht, 1987). Storage periods of $\leq 7 \mathrm{~d}$ at 12.5 ${ }^{\circ} \mathrm{C}$ did not significantly affect fruit softening, confirming that this temperature is an acceptable storage temperature to maintain firmness of tomatoes.

The delay in ripening after chilling exposure in our experiments is similar to that reported by Rosa (1926) and Saltveit and Cabrera (1987) for tomatoes. Because of softening and uneven coloration, the least mature tomatoes and those stored at $2.5^{\circ} \mathrm{C}$ before ethylene treatment had shorter marketable lives than the more mature tomatoes and those treated with ethylene before storage. Softening and uneven coloration have previously been reported as symptoms of chilling injury in tomatoes (Morris, 1954). In our experiments, storage for $9 \mathrm{~d}$ at 2.5 ${ }^{\circ} \mathrm{C}$ caused an irreversible chilling damage to the fruit regardless of the time of ethylene application, hence, shortening the marketable life. Storage at $\mathbf{2 . 5}$ ${ }^{\circ} \mathrm{C}$ before ethylene treatment shortened the marketable life more dramatically than storage after ethylene treatment. This is in agreement with earlier work that showed that tomatoes at the breaker stage are more tolerant of chilling temperature than green fruit (Ryall and Lipton, 1979).

Since tomatoes pretreated with ethylene had developed incipient color before storage at $2.5^{\circ} \mathrm{C}$, while the untreated fruit were still green on the first day of storage at $2.5^{\circ} \mathrm{C}$, differences in the ultimate color and appearance of these groups of tomatoes probably were due to differences in the progression of chlorophyll-chloroplast conversion when chilling commenced (Marangoni et al., 1989). The color development of fruit treated with eth-

Table 6. Composition of red stage tomatoes treated with ethylene at $20{ }^{\circ} \mathrm{C}\left(68{ }^{\circ} \mathrm{F}\right)$ before or after storage in air at $2.5{ }^{\circ} \mathrm{C}$ $\left(36.5{ }^{\circ} \mathrm{F}\right)$ for $3,5,7$, or $9 \mathrm{~d}$ then allowed to ripen in air at $20^{\circ} \mathrm{C}$.

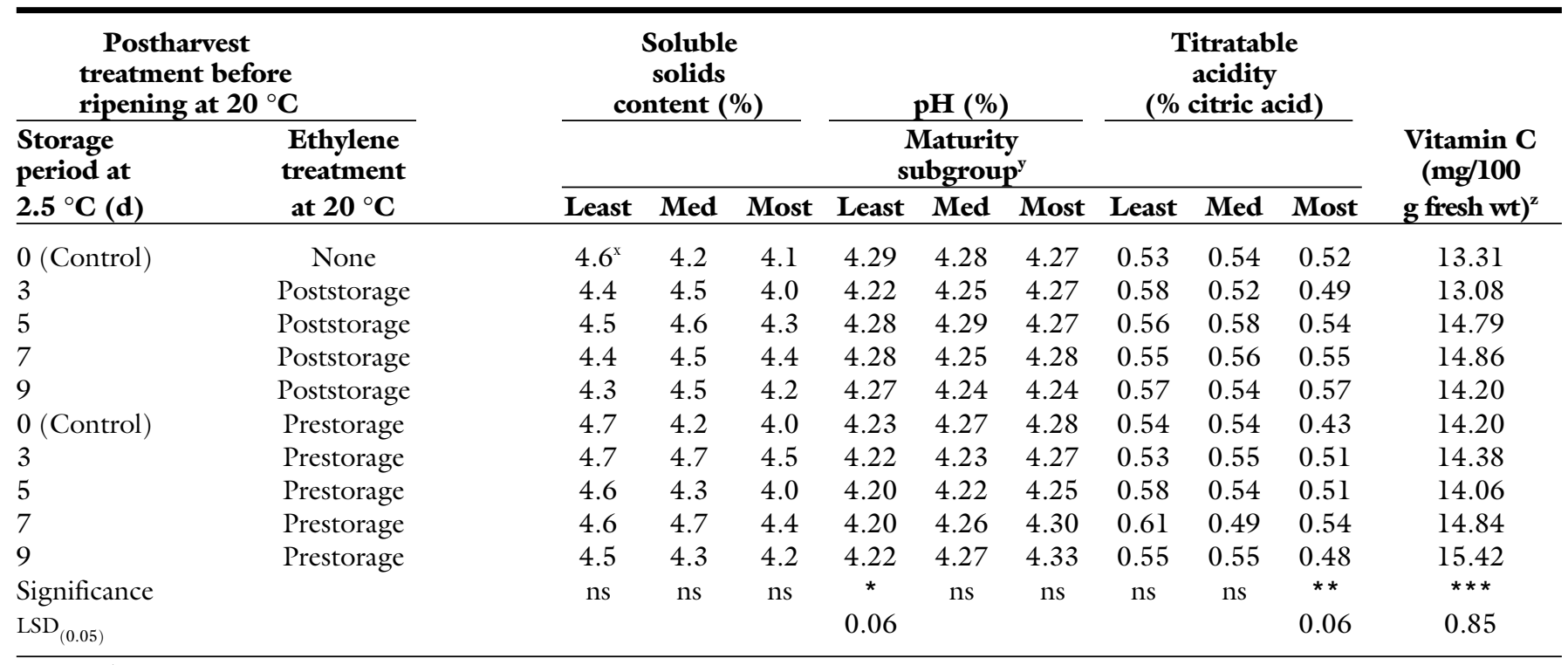

${ }^{\mathrm{z}} 1.00 \mathrm{mg} / 100 \mathrm{~g}=10 \mathrm{ppm}$

yLeast $=$ least mature fruit; med $=$ medium mature fruit; most $=$ most mature fruit.

${ }^{x}$ Means are the average of nine (vitamin $C$ ) or three 5 -fruit replications.

Ns, ${ }^{\star \star \star *},{ }^{\star \star *}$ Nonsignificant or significant at $P<0.05,0.01$, or 0.001 , respectively. 
ylene before storage started before and continued during storage. The final color of these fruit was orange-red, indicating that chilling temperatures affected pigment development after the conversion was initiated. In contrast, the color initiation of fruit stored at $2.5{ }^{\circ} \mathrm{C}$ beginning on the day of harvest was inhibited. The chloroplastchromoplast conversion in these fruit may have been damaged, thus, the fruit developed blotchy coloration.

The chemical analysis of green tomatoes showed lower $\mathrm{pH}$ and higher TA with increasing maturity. This is in agreement with the results of Stevens (1972) indicating that TA increases during tomato development and reaches its highest level near the appearance of incipient color. When $\mathrm{pH}$ and TA at harvest and at the red stage were compared, $\mathrm{pH}$ was reduced and TA increased. This may be explained by the findings of Hall (1968) and Buescher (1975) that low temperature causes citric acid accumulation in tomatoes. Such an accumulation may be due to suppression of respiration at low temperature (Lyons and Raison, 1970). There were little or no differences in SSC and vitamin C between the maturity stages at harvest. Since it is well established that both SSC and vitamin C increase during tomato development (Davies and Hobson, 1981), this result suggests that the range of maturities in these commercial harvests was fairly narrow. However, storage at $12.5^{\circ} \mathrm{C}$ resulted in higher SSC and vitamin C levels at the red stage in the less mature tomatoes, which was also true for SSC in $2.5^{\circ} \mathrm{C}$-stored fruit, but not for vitamin C. Lack of a maturity effect on vitamin $\mathrm{C}$ at the red stage following storage at $2.5^{\circ} \mathrm{C}$ suggests that loss of vitamin $\mathrm{C}$ related to chilling injury was more likely to be from the least mature fruit than from the more mature fruit, since the initial vitamin $C$ of the least mature fruit was higher at harvest. This result is in agreement with the reports by Craft and Heinze (1954) and Liptay et al. (1986).

\section{Conclusions}

'Sunny' tomatoes held for longer periods of time at $\leq 7.5^{\circ} \mathrm{C}$ exhibited increasingly delayed and uneven (blotchy) ripening with lack of ripening uniformity. The marketable life of tomatoes was prolonged by storage at $12.5^{\circ} \mathrm{C}$ compared to storage at 2.5 ${ }^{\circ} \mathrm{C}$, but conversely decreased with increasing storage time. Tomatoes treated with ethylene beginning on the day of harvest and allowed to ripen in air at $20^{\circ} \mathrm{C}$ ripened faster and more uniformly and, additionally, had enhanced marketable life beyond the red stage compared to cold-stored fruit. Storage at $12.5^{\circ} \mathrm{C}$ delayed the ripening processes compared to $20^{\circ} \mathrm{C}$, but once the fruit were transferred from $12.5^{\circ} \mathrm{C}$ to $20^{\circ} \mathrm{C}$, ripening was enhanced. Postponing ethylene treatment until after storage resulted in delayed fruit ripening that was more pronounced with longer storage either at 2.5 or $12.5^{\circ} \mathrm{C}$. The marketable life of tomatoes held at $2.5^{\circ} \mathrm{C}$ was prolonged by prestorage ethylene treatment, but not with poststorage ethylene treatment. Treating green tomatoes with ethylene before storage or transport is therefore preferable to poststorage treatment because of faster and more uniform ripening, and also increased marketable life and reduced risk of injury in the event of exposure to chilling temperatures.

\section{Literature cited}

Abou Aziz, A.B., M.M. Abdel Maksoad, K.A. Abdel-Samie, and A.A. Kader. 1974. Effect of picking stage and temperature on quality and ripening of tomato fruit. Gartenbauwissenschaft 39:37-45.

Ahrens, M.J. and D.J. Huber. 1990. Physiology and firmness determination of ripening tomato fruit. Physiol. Plant. 78:8-14.

Autio, W.R. and W.L. Bramlage. 1986. Chilling sensitivity of tomato fruit in relation to ripening and senescence. J. Amer. Soc. Hort. Sci. 111:201-204.

Baker, E.A., M.J. Bukovac, and G.M. Hunt. 1982. Composition of tomato fruit cuticle as related to fruit growth and development, p. 33-44. In: D.F. Culter, K.L. Alvin, and C.E. Price (eds.). The plant cuticle. Academic Press, New York.

Brecht, J.K. 1987. Locular gel formation in developing tomato fruit and the initiation of ethylene production. HortScience $22: 476-479$.

Brown, E.D., R.Y. Yada, and D.W. Stanley. 1989. Chilling injury and modified atmosphere storage of mature green tomatoes. Can. Inst. Food Sci. Technol. J. 22:339344.

Buescher, R.W. 1975. Organic acid and sugar levels in tomato pericarp as influenced by storage at low temperature. HortScience 10:158-159.

Burg, S.P. and E.A. Burg. 1967. Molecular requirements for biological activity of ethylene. Plant Physiol. 42:144-147.

Craft, C.C. and P.H. Heinze. 1954. Physiological studies of mature-green tomatoes in storage. Proc. Amer. Soc. Hort. Sci. 64:343-350.

Davies, J.N. and G.E. Hobson. 1981. The constituents of tomato fruit-The influence of environment, nutrition, and genotype. Crit. Rev. Food Sci. Nutr. 15:205280.

Dodds, G.T. and P.M. Ludford. 1990. Surface topology of chilling injury of tomato fruit. HortScience 25:1416-1419.

Dodds, G.T., J.W. Brown, and P.M. Ludford. 1991. Surface color changes of tomato and other solanaceous fruit during chilling. J. Amer. Soc. Hort. Sci. 1 16:482490 .

Florida Tomato Committee. 1990. Annual report 1989-1990. Fla. Tomato Comm., Orlando.

Francis, F.J. 1970. Color measurement in plant breeding. HortScience 5:10-14.

Goodenough, P.W., G.A. Tucker, D. Grierson, and T. Thomas. 1982. Changes in color, polygalacturonase, monosaccharides, and organic acids during storage of tomatoes. Phytochemistry 21:281-284.

Gull, D.D. 1989. Delay in ripening initiation of Florida green tomatoes. Vegetarian Nwslt. 89-09.

Hall, C.B. 1965. Effect of holding justturned tomato fruits at $45^{\circ} \mathrm{F}$ prior to ripening at $68^{\circ} \mathrm{F}$. Fla. State Hort. Soc. 78:24l-244.

Hall, C.B. 1968. Changes in titratable acidity of tomato fruits subject to low temperatures. HortScience 3:37-38.

Hardenburg, R.E., A.E. Watada, and C.Y. Wang. 1986. The commercial storage of fruits, vegetables, and florist and nursery stocks. USDA Agr. Hndbk. 66.

Hobson, G.E. 1987. Low-temperature injury and the storage of ripening tomatoes. J. Hort. Sci. 62:55-62.

Inaba A., T. Yamamoto, T. Ito, and R. Nakamura. 1980. Comparison of ripening and sensory characteristics of attached and detached tomato fruits. J. Jpn. Soc. Hort. Sci. 49:132-138.

Jackman, R.L., R.Y.Yada, A.G. Marangoni, K.L. Parkin, and D.W. Stanley. 1989. Chilling injury: A review of quality aspects. J. Food Qual. 11:253-278.

Jeffery, D., C. Smith, P. Goodenough, I. Prosser, and D. Grierson. 1984. Ethyleneindependent and ethylene-dependent biological changes in ripening tomatoes. Plant Physiol. 74:32-38. 
Kader, A.A. and L.L. Morris. 1976. Correlating subjective and objective measurements of maturation and ripeness of tomatoes, p. 57-62. In: Proc. 2nd Tomato Qual. Wkshp., Univ. Calif., Davis.

Kader, A.A., L.L. Morris, M.A. Stevens, and M. Albright-Holton. 1978. Composition and flavor quality of fresh market tomatoes as influenced by some postharvest handling procedures. J. Amer. Soc. Hort. Sci. 103:6-13.

Kader, A.A., M.A. Stevens, M. AlbrightHolton, and L.L. Morris. 1977. Effect of fruit ripeness when picked on flavor and composition in fresh market tomatoes. J. Amer. Soc. Hort. Sci. 102:724-731.

Kasmire, R.F. and A.A. Kader. 1978. Handling tomatoes at wholesale and retail: A guide for better quality and greater profits. Outlook 5(3):5-12.

Kattan, A.A. 1957. Changes in color and firmness during ripening of detached tomatoes and the use of a new instrument for measuring firmness. Proc. Amer. Soc. Hort. Sci. 70:379-384.

Liptay, A., A.P. Papadopoulos, H.H. Bryan, and D. Gull. 1986. Ascorbic acid levels in tomato (Lycopersicon esculentum Mill.) at low temperature. Agr. Biol. Chem. 50:3185-3187.

Lyons, J.M. and J.K. Raison. 1970. Oxidative activity of mitochondria isolated from plant tissue sensitive and resistant to chilling injury. Plant Physiol. 45:386-389.

Marangoni, A.G., R.L. Jackman, and D.W. Stanley. 1995. Chilling-associated softening of tomato fruit is related to increased pectinmethylesterase activity. J. Food Sci. 60:1277-1281.

Marangoni, A.G., A.K. Smith, R.Y. Yada, and D.W. Stanley. 1989. Ultrastructural changes associated with chilling injury in mature-green tomato fruit. J. Amer. Soc. Hort. Sci. 114:958-962.

McColloch, L.P. and J.T. Worthington. 1952. Low temperature as a factor in the susceptibility of mature-green tomatoes to alternaria rot. Phytopathology 42:425427.
McDonald, R.E., T.G. McCollum, and E.A. Baldwin. 1999. Temperature of water heat treatments influences tomato fruit quality following low-temperature storage. Postharvest Biol. Technol. 16:147-155.

Moline, H.E. 1976. Ultrastructural changes associated with chilling of tomato fruit. Phytopathology 66:617-624.

Morris, L.L. 1954. Field and transit chilling of fall-grown tomatoes. Proc. Conf. Transportation Perishables, Univ. Calif., Davis.

Pratt, H.K. and M. Workman. 1962. Studies on the physiology of tomato fruits. III The effect of ethylene on respiration and ripening behavior of fruits stored at $20^{\circ} \mathrm{C}$ after harvest. Proc. Amer. Soc. Hort. Sci. 81:467-478.

Rosa, J.T. 1926. Ripening and storage of tomatoes. Proc. Amer. Soc. Hort. Sci. 23:233-242.

Ryall, A.L. and W.J. Lipton. 1979. Handling, transportation and storage of fruits and vegetables. vol. 1. Vegetables and melons. 2nd ed. AVI Publ. Co., Westport, Conn.

Saltveit, Jr., M.E. and R.M. Cabrera. 1987. Tomato fruit temperature before chilling influences ripening after chilling. HortScience 22:452-454.

SAS Institute. 1986. Statistical analysis systems computer package. SAS Inst., Cary, N.C.

Stevens, M.A. 1972. Citrate and malate concentrations in tomato fruits: Genetic control and maturational effects. J. Amer. Soc. Hort. Sci. 97:655-658.

Terada, M., Y. Watanabe, M. Kunitomo, and E. Hayashi. 1978. Differential rapid analysis of ascorbic acid and ascorbic acid-2sulfate by dinitrophenylhydrazine method. Anal. Biochem. 84:604-608.

Wang, C.Y. 1982. Physiological and biochemical responses of plants to chilling stress. HortScience 17:173-195.

Whitaker, B.D. 1991. Changes in lipids of tomato fruit stored at chilling and nonchilling temperatures. Phytochemistry 30:761-767.
Reduced Tillage

Practices for

Summer Squash

Production in

Southern Illinois

\author{
S. Alan Walters ${ }^{1}$ and \\ Jeffrey D. Kindhart ${ }^{2}$
}

Additional IndeX WORds. Cucurbita pepo, conservation tillage, vegetable production

Summary. Various tillage systems were evaluated in summer squash (Cucurbita pepo) production in southern Illinois to observe the influence of these systems on yellow and zucchini squash production during 1998, 1999, and 2000. For squash production, suppression of a cover crop such as tall fescue (Festuca arundinacea) or winter ryegrass (Secale cereale) must be accomplished to obtain the greatest possible yields. However, once the cover crop is killed via herbicides, squash yields tend to be similar among tillage, strip tillage, and no-tillage treatments. Previous studies indicated that early yields may be reduced when using a no-tillage production system, especially if direct seeding is the method of planting and would not be beneficial to growers seeking early production. This study found that squash growers can use transplants in a no-tillage system and not compromise early yields. No differences were observed for soil bulk densities between tillage and no-tillage treatments and may partially explain why similar yields were obtained between these treatments. Effective systems for weed control must be developed in no-tillage squash production before wide acceptance will occur. Observations from this study indicated that the success of no-tillage squash production depends on the availability of effective herbicides; however, few herbicides are currently labeled for use in summer squash. Future studies need to address the problem of weed control in no-tillage squash production.

The research reported in this publication was funded by the Illinois Council for Food and Agricultural Research (C-FAR). The use of trade names in this publication does not imply endorsement of the products named, nor criticism of similar ones not mentioned.

${ }^{1}$ Assistant professor, Department of Plant, Soil, and General Agriculture, Southern Illinois University, Carbondale, Ill. 62901-4415.

${ }^{2}$ Senior research specialist-horticulture, Dept. of Natural Resources and Environmental Sciences, University of Illinois, Dixon Springs Agricultural Center, Simpson, Ill. 62985 . 